\title{
Corporate Ownership Structure and the Choice Between Bank Debt and Public Debt*
}

\author{
Chen Lin \\ Chinese University of Hong Kong \\ Paul Malatesta \\ University of Washington
}

\author{
Yue Ma \\ Lingnan University, Hong Kong \\ Yuhai Xuan \\ Harvard Business School
}

Forthcoming, Journal of Financial Economics

\begin{abstract}
We examine the relation between a borrowing firm's ownership structure and its choice of debt source using a novel, hand-collected data set on corporate ownership, control and debt structures for 9,831 firms in 20 countries from 2001 to 2010 . We find that the divergence between control rights and cash-flow rights of a borrowing firm's largest ultimate owner has a significant impact on the firm's choice between bank debt and public debt. A one-standard-deviation increase in the divergence reduces the borrowing firm's reliance on bank debt financing (measured by the ratio of bank debt to total debt) by approximately $23 \%$. The effect of the control-ownership divergence on borrowing firms' debt choice is more pronounced for firms with high financial distress risk, firms that are informationally opaque, and firms that are family-controlled. Moreover, this effect is weakened by the presence of multiple large owners and in countries with strong shareholder rights. In addition, we find that the control-ownership divergence affects other aspects of debt structure such as debt maturity and security. Overall, our results are consistent with the hypothesis that firms controlled by large shareholders with excess control rights choose public debt financing over bank debt as a way of avoiding scrutiny and insulating themselves from bank monitoring.
\end{abstract}

JEL classification: G21; G32

Keywords: Ownership structure; Bank Debt; Public Debt

${ }^{*}$ We thank an anonymous referee, Ben Esty, Paul Gompers, Joel Houston, Andrei Shleifer, Bill Schwert (the editor), Belén Villalonga, and seminar participants at Nanyang Business School for thoughtful comments and suggestions. We thank Pennie Wong for help with data collection. Lin and Xuan gratefully acknowledge financial support from the Chinese University of Hong Kong and the Division of Research of the Harvard Business School, respectively. 


\section{Introduction}

Why do some firms borrow mainly from arm's length investors such as public bondholders while others rely much more on informed financial intermediaries such as banks as their debt providers? This is an important question as both bank loans and public bonds are major sources of global corporate financing. ${ }^{1}$ Existing corporate theories provide various explanations for the benefits and costs of using bank debt versus public debt (e.g., Diamond, 1984, 1991; Fama, 1985; Rajan, 1992; Park, 2000). Yet, despite the theoretical and empirical importance of credit markets, there is only limited evidence on the determinants of the choice between private and public debt financing. For instance, using a panel data set of 250 publicly listed firms in the U.S., Houston and James (1996) investigate the relation between a firm's growth opportunities and its mix of private and public debt claims. More recently, Denis and Mihov (2003) examine the link between a firm's credit quality and its choice of debt source. Most of the existing studies focus on firms in the U.S. and explore firm financial characteristics as potential factors influencing firms' debt choices. In this paper, we focus on the ownership structure of borrowing firms. Specifically, we explore the effect of the divergence between ownership and control on debt choice using a unique, hand-collected international panel data set that covers more than 9,800 firms in 20 countries from 2001 to 2010.

Existing theories on ownership structure and corporate debt financing choice offer different views on the relation between firm control-ownership divergence and the choice between bank debt and public debt. On the one hand, compared to public debt holders, banks have significant comparative advantages in monitoring efficiency due to access to private information as insiders (Fama, 1985). Superior access to information enables banks to detect expropriation or opportunistic activities by controlling shareholders and corporate insiders and, accordingly, to

\footnotetext{
${ }^{1}$ Using the year 2009 as an example, international syndicated lending alone amounted to \$1.8 trillion and, meanwhile, corporations borrowed another $\$ 1.5$ trillion in international bond markets (Chui et al., 2010).
} 
punish the offending borrowers either by liquidation or through renegotiation (Park, 2000). As a consequence, bank monitoring reduces moral hazard problems and provides borrowers strong incentives to make appropriate corporate decisions (Stiglitz and Weiss, 1983; Rajan, 1992). In contrast, the diffuse ownership of public debt and the resulting free rider problems weaken individual bondholders' incentives to engage in costly monitoring (Diamond, 1984 and 1991). Even if many bondholders were willing to monitor, the monitoring itself would be inefficient as it would involve wasteful duplication of monitoring efforts and costs (Houston and James, 1996). In short, the combination of concentrated holdings, credible threats, and superior access to information makes banks much more effective monitors than public bondholders in deterring potential self-interested or self-dealing activities. ${ }^{2}$ Therefore, controlling shareholders and corporate insiders are less likely to be able to extract private benefits at the expense of other shareholders under bank monitoring (Hoshi et al., 1993). From this perspective, firms with greater monitoring needs (e.g., those with greater agency problems) should borrow privately from banks while firms with lower monitoring needs should borrow more from arm's length public investors (Houston and James, 1996; Denis and Mihov, 2003). Since the divergence between ownership and control induces significant agency problems between large shareholders and other investors (e.g., Shleifer and Vishny, 1999), it follows that there should be a positive relation between corporate control-ownership divergence and the borrowing firm's reliance on bank debt. ${ }^{3}$

On the other hand, controlling shareholders' incentives to engage in expropriation activities and elude monitoring may imply the opposite relationship between the control-ownership divergence and firm debt choice. The literature on corporate ownership structure documents

\footnotetext{
${ }^{2}$ This is consistent with evidence based on stock market reactions documented in James (1987), which shows that the stock market reacts more positively to firm announcements of bank loans than to announcements of public debt offerings.

${ }^{3}$ It is possible that the link between control-ownership divergence and bank debt reliance weakens when bank debt accumulates to a certain level beyond which banks' incremental monitoring incentives get smaller. We explore this possibility in Section 3.3.2.
} 
widespread divergences between the control and cash-flow rights of dominant shareholders. These divergences arise from the use of pyramid ownership structures, multiple control chains, and dual-class shares in many public firms around the world (e.g., La Porta et al., 1999; Claessens et al., 2000). In such firms, the high control rights enable the controlling shareholders to engage in various self-dealing activities to divert corporate resources for private benefits while the low cash-flow rights expose the controlling shareholders to very limited direct financial costs of such activities (Shleifer and Vishny, 1997; Johnson et al., 2000). ${ }^{4}$ Consequently, the tunneling incentives in these firms increase with the wedge between control rights and cash-flow rights. Tunneling activities by controlling shareholders heighten the risk of financial distress and default, impair collateral value, and increase expected bankruptcy costs. Taking these agency costs into account, banks are more likely to impose particularly strong monitoring on borrowing firms with large divergences between ownership and control. ${ }^{5}$ In anticipation of the strict monitoring by banks, firms controlled by large shareholders with excess control rights might prefer public debt financing over bank debt as a way of avoiding scrutiny and insulating themselves from bank monitoring (Houston and James, 1996; Denis and Mihov, 2003). These considerations, therefore, suggest a negative relation between corporate control-ownership divergence and a borrowing firm's reliance on bank debt.

The overall effect of the borrowing firm's control-ownership divergence on its choice between bank debt and public debt is an empirical question that we explore in this paper. To investigate this, we construct a new, hand-collected large data set on corporate ownership structure and debt structure for more than 9,800 publicly listed firms across 20 East Asian and West European countries during the period 2001-2010. ${ }^{6}$ Using this large international data set,

\footnotetext{
${ }^{4}$ Examples of these activities include asset sales, asset and cash flow transfers, inter-corporate loans, and investment activities that generate private benefits for the controlling shareholders while harming firm performance as well as the interests of other investors (see, e.g., Johnson et al., 2000 and Djankov et al., 2008).

${ }^{5}$ Indeed, Lin et al., (2012) find strong evidence that banks form syndicates with structures that facilitate monitoring when the control-ownership divergence is large.

${ }^{6}$ We focus on these East Asian and Western European countries because it has been documented that the
} 
we find strong evidence that is consistent with the bank monitoring avoidance hypothesis. Our results indicate that firms with wider divergences between controlling shareholders' voting rights and cash-flow rights tend to rely more heavily on public debt financing and less on bank debt financing. The effect is not only statistically significant but also economically significant. A one-standard-deviation increase in the difference between the control rights and cash-flow rights of the largest ultimate owner of the borrowing firm, or the control-ownership wedge, reduces the firm's reliance on bank debt financing (measured by the ratio of bank debt to total debt) by 16 percentage points, ceteris paribus. This is an economically significant effect given the sample average bank debt to total debt ratio of $71 \%$. Consistently, an increase in the control-ownership wedge significantly increases the firm's reliance on public debt financing. Our baseline results support the argument that firms controlled by large shareholders with excess control rights choose public debt financing over bank debt as a way of avoiding bank scrutiny and monitoring.

We further test the monitoring avoidance hypothesis by investigating whether the relation between the control-ownership wedge and debt choice is influenced by factors that affect controlling shareholders' incentives to evade monitoring. The negative effect of the controlownership divergence on borrowing firms' reliance on bank debt (i.e., the monitoring avoidance effect) should be particularly strong in situations where the control-ownership divergence is more likely to result in intensive bank monitoring. Moreover, the effect should also be enhanced in the presence of factors that increase dominant shareholders' tunneling incentives and, as a result, their incentives to avoid bank monitoring. Specifically, we examine five factors: firm financial distress risk, information opacity, family ownership, the presence of multiple large shareholders, and the strength of shareholder rights.

control-ownership divergence is prevalent and has significant effects on firm value among firms in these countries (e.g., Claessens et al., 2000). Following Houston and James (1996), we focus on publicly listed firms because these firms are most likely to find public debt financing feasible and thus most likely to confront the choice between bank debt and public debt. 
We find that firms with high financial distress risk and firms with high degrees of information opacity tend to rely more on bank debt financing. These effects are consistent with the major advantages of bank debt financing over public debt financing highlighted in the existing literature. These advantages include renegotiation efficiency and re-contracting flexibility during financial distress, low-cost information production, and the ability to price claims that are hard for public investors to value in firms with high levels of information asymmetry (e.g., Ramakrishnan and Thakor, 1984; Gilson et al., 1990; Thakor and Wilson, 1995; Hadlock and James, 2002; Denis and Mihov, 2003). More important, we find that firm financial distress risk and information opacity strengthen the negative relation between the controlownership wedge and bank debt reliance. Since financial distress risk and information opacity raise controlling shareholders' tunneling incentives and at the same time increase the expected monitoring from banks (e.g., Campello et al., 2011; Lin et al., 2012), controlling shareholders' incentives to elude monitoring also increase. This results in a more pronounced effect of controlownership divergence on debt choice. To state this differently, the presence of controlownership divergence weakens the positive links between financial risk and bank debt reliance and between information opacity and bank debt reliance because of controlling shareholders' sharpened incentives to avoid bank scrutiny.

With respect to ownership identity, tunneling incentives are likely to be particularly strong when a firm's controlling shareholder is an individual or a family because the private benefits of control are not diluted among many unrelated investors (Villalonga and Amit, 2006). Consequently, family-controlled firms may have heightened incentives to avoid bank monitoring. Consistent with the monitoring avoidance hypothesis, we find that the effect of controlownership divergence on firm debt choice is larger for family-controlled firms.

In contrast, we find that the relation between control-ownership divergence and debt choice is weakened by the presence of multiple large shareholders and in countries with strong shareholder rights. Having other large owners and strong shareholder rights reduces the 
tunneling incentives of the controlling shareholder (e.g., Maury and Pajuste, 2005; La Porta et al., 1998; Djankov et al., 2008). As a result, the controlling shareholder's incentive to avoid bank monitoring is also reduced, resulting in a lesser impact of the control-ownership wedge on bank debt reliance.

We conduct a battery of ancillary tests to rule out alternative explanations and verify the robustness of our results. While our results are consistent with dominant shareholders avoiding bank monitoring due to their tunneling incentives, controlling shareholders may also have incentives to prop up a financially distressed firm using transfers from other firms under their control in order to preserve their options to expropriate profits of this specific firm in the future (e.g., Friedman et al., 2003). In such cases, firms with controlling shareholders might also find bank debt less attractive because the benefits of bank debt financing during financial distress such as renegotiation efficiency and re-contracting flexibility (e.g. Gilson et al., 1990; Denis and Mihov, 2003) become less valuable. We therefore control for a borrowing firm's potential of being propped up and test the robustness of our main results. Specifically, we construct measures of a borrowing firm's propping potential based on the value of the assets of all firms that are positioned underneath the firm in the ownership chain and could potentially be used to prop it up (Lin et al., 2011). ${ }^{7}$ Our main findings remain economically and statistically significant after controlling for borrowing firms' propping potentials. We also repeat the baseline regressions in the subsample of firms likely to have little or no potential of being propped up (i.e., firms at the bottom of the ownership chain) and find highly robust results. In addition, we exclude firms with no controlling shareholders and focus on only firms that have controlling shareholders to explore whether the control-ownership divergence still has any explanatory power for debt choice in this subsample of firms that are all subject to potential propping. We

\footnotetext{
${ }^{7}$ As documented in the ownership literature (e.g., Bertrand et al., 2002), controlling shareholders are most likely to transfer capital and resources from firms in which they have low cash-flow rights (i.e., firms low down in the ownership chain) to prop up firms in which they have high cash-flow rights (i.e., firms high up in the ownership chain).
} 
continue to find that the control-ownership wedge exerts a significant and negative impact on firm's bank debt reliance.

In another set of tests, we investigate whether the level of existing bank debt in a firm's debt structure affects the relation between control-ownership divergence and debt choice. While an increase in financial stake and thus credit exposure in the borrowing firm enhances banks' incentives to exert effort in due diligence and monitoring (Sufi, 2007), it is possible that for firms with high levels of bank debt, the change in bank monitoring may not be very sensitive to the change in the control-ownership wedge because these firms are already subject to strict bank monitoring. Consequently, the effect of control-ownership divergence on debt choice may be less pronounced when bank debt accumulates to a certain level beyond which banks' incremental monitoring incentives get smaller. Indeed, we find that the link between the control-ownership wedge and bank debt reliance weakens for firms with high levels of bank debt.

Another issue that we address concerns the possibility that some unobserved or omitted factor may drive both a firm's ownership structure and its debt choice, thus biasing our findings. We employ several different methods to address this potential concern. First, we include country and industry fixed effects as well as year interaction (e.g., country×year) fixed effects in our regressions to control for time-invariant and time-varying factors that may affect both ownership structure and debt choice. Second, we perform change regressions to explore the effect of a change in a firm's ownership structure on the change in the firm's debt choice. Examining changes helps to control for time-invariant omitted factors that might be driving the results. Third, we test the robustness of our results using instrumental variable analyses. The empirical results from all of these additional tests are highly robust. We find that a firm's ownership structure continues to significantly influence its debt choice after accounting for the potential issue of endogeneity.

In addition to debt source, we also explore the impact of control-ownership divergence on other aspects of debt structure such as debt maturity and security. The tunneling and monitoring 
avoidance incentives of the controlling shareholders might also affect debt maturity and security for two reasons. First, short-maturity debt increases monitoring intensity since the borrowing firm is subject to more frequent scrutiny by creditors, underwriters, and rating agencies at issuance or renewal (Stulz, 2000; Datta et al., 2005). Similarly, having collateral increases creditors' monitoring incentives. This is because collateral enables creditors to garner higher returns from monitoring when the borrowing firm is in distress (Rajan and Winton, 1995; Park, 2000). In anticipation of the intensive monitoring induced by short maturity and high security requirements, firms controlled by large shareholders with tunneling incentives would prefer to insulate themselves by choosing a debt structure with long maturity and low levels of collateralization (Datta et al., 2005). Second, as has been widely documented in the literature, bank debt on average has a much shorter maturity (e.g., Tufano, 1993; Stohs and Mauer, 1996; Johnson, 1997; Park, 2000) and is more often secured by collateral (e.g., Gilson and Warner, 2000) than public debt. Given our main finding that firms with wider control-ownership divergence tend to rely more on public debt and less on bank debt, we would also expect the control-ownership wedge to be positively related to debt maturity and negatively related to debt security. Our empirical results are highly consistent with our expectations. We find that the control-ownership divergence significantly affects borrowing firms' debt maturity and security: firms with larger control-ownership wedges tend to have debt with longer maturities and lower levels of collateralization.

Our paper contributes to several strands of literature. The primary contribution to the debt choice literature is to show that the control-ownership divergence has a first order effect on a borrowing firm's debt structure. ${ }^{8}$ To our knowledge, ours is the first paper to report evidence on this effect. Taken together, our findings show that the monitoring avoidance incentives caused by the control-ownership divergence play an important role in determining firm debt choice. Our paper also contributes to the ownership structure literature (e.g., La Porta et al., 1999;

\footnotetext{
${ }^{8}$ See Kale and Meneghetti (2010) for a recent survey of this literature.
} 
Claessens et al., 2000; Lin et al., 2012) by presenting a new insight on how elements of corporate ownership structure exacerbate large shareholders' moral hazard problems, influence firm financial decisions, and shape corporate policies. In addition, the paper adds to the law and finance literature (e.g., La Porta et al., 1998; Djankov et al., 2008) by showing how law and institutions mitigate the impact of controlling shareholders' tunneling incentives on debt financing decisions.

The remainder of the paper proceeds as follows. We discuss the sample construction process and variable definitions in Section 2. Section 3 presents the empirical results from the baseline regressions, the robustness checks, and the finer tests focusing on the interaction between ownership structure and various other factors. We conclude the paper in Section 4.

\section{Data and variables}

\subsection{Sample construction}

To investigate the effect of a firm's ownership structure on its choice between bank and public debt, we assemble a large international data set on corporate ownership, control, and debt structures. Our sample construction process starts with the Capital IQ database, which provides extensive financial data on over 50,000 public and private firms around the world. From Capital IQ, we obtain detailed information on the debt structure, including the types of debt and the amount for each type, along with other relevant financial data, for all public firms with nonzero debt in 20 East Asian and Western European countries from 2001 to $2010 .^{9}$ The 20 countries are: Austria, Belgium, Finland, France, Germany, Hong Kong, Ireland, Italy, Japan, Malaysia, Norway, Portugal, Singapore, South Korea, Spain, Sweden, Switzerland, Taiwan, Thailand, and

\footnotetext{
${ }^{9}$ The Capital IQ database categorizes the total debt into various types such as term loans, credit lines, senior bonds and notes, subordinated bonds and notes, commercial paper, capital leases, and other debt. We exclude from our sample firms in the financial and regulated utilities industries.
} 
the United Kingdom. We focus on these countries because firms in these regions are often controlled by large shareholders through pyramid structures or dual class shares, where the control-ownership divergence is prevalent and has significant effects on firm value and corporate outcomes (e.g., Claessens et al., 2000; Faccio and Lang, 2002; Lin et al., 2012). ${ }^{10}$ Following Houston and James (1996), we focus on publicly listed firms because these firms are most likely to find public debt financing feasible and, as a consequence, are most likely to confront the choice between bank debt and public debt.

For each firm in the sample, we then hand-collect information on the ownership and control rights of its largest ultimate owner using the ORBIS database. ORBIS provides direct ownership information for more than 50 million public and private firms around the world. We supplement ORBIS with ownership information collected from FactSet and company annual reports. For each firm, we map out the complete chain of corporate ownership by first identifying all the large shareholders of the firm, which are often corporations themselves, and then tracing each of these shareholders through multiple layers of ownership along the chain until we reach the ultimate ownership level. An ultimate owner can be an individual, a family, a government, or a widely held corporation. A firm is defined as widely held, i.e., having no large shareholders, if none of its owners has $10 \%$ or more of the voting rights (e.g., La Porta et al., 1999). ${ }^{11}$

To be retained in the sample, a firm must have available debt and financial information from Capital IQ and complete ownership chain information from ORBIS. We exclude firms with zero debt from the sample. For our sample countries, less than 5\% of firms in Capital IQ have zero debt. Our final sample thus consists of 43,502 firm-year observations covering 9,831

\footnotetext{
${ }^{10}$ Specifically, Claessens et al. (2000) and Faccio and Lang (2002) show significant divergence in corporate ownership and control in 22 East Asian and Western European countries, including the 20 countries we study in this paper plus Indonesia and Philippines. We start our sample construction process with the original 22 countries covered in Claessens et al. (2000) and Faccio and Lang (2002) and then require a country to have a bond market capitalization-to-GDP ratio of at least $10 \%$ to be retained in the sample. Indonesia and Philippines are thus eliminated from our sample because they do not have well-developed bond markets (i.e., bond market capitalization/GDP $<10 \%$ ).

${ }^{11}$ Using alternative thresholds, such as $15 \%$ or $20 \%$, does not materially alter our results.
} 
firms in 20 countries from 2001 to 2010 . The number of firms per country ranges from 41 in Portugal to 2,613 in Japan, with a sample average of 492.

\subsection{The control-ownership divergence of the largest ultimate owner}

Mapping out the complete ownership chain for each sample firm allows us to clearly identify all ultimate owners of the firm and compute their respective cash-flow rights and control rights, including both the direct and the indirect rights. The direct rights of an ultimate owner are based on direct ownership of shares held under the owner's name. The indirect rights are afforded by shares held by other entities along the ownership chain controlled by the ultimate owner. Indirect cash-flow rights and control rights are calculated according to the standard definitions in the ownership literature (e.g., Claessens et al., 2000). Indirect cash-flow rights are calculated as the product of cash-flow ownership stakes along the ownership chain. Indirect control rights are measured by the weakest link in the chain of control rights. For example, if firm A owns $20 \%$ of the shares of firm B which, in turn, owns $15 \%$ of the shares of firm C, then firm A's indirect cash-flow rights and indirect control rights in firm C are $3 \%(=20 \% \times 15 \%)$ and $15 \%(=\min (20 \%, 15 \%))$, respectively. Summing up an ultimate owner's direct and indirect cashflow (control) rights yields its aggregate cash-flow (control) rights. The largest ultimate owner is defined as the ultimate owner with the greatest aggregate control rights.

To capture the degree of control-ownership divergence in a firm's ownership structure, we define our key measure, the control-ownership wedge, as the difference between the control rights and the cash-flow rights of the largest ultimate owner of the firm. ${ }^{12}$ The larger a firm's wedge, the greater deviation there is between ownership and control at the firm and,

\footnotetext{
${ }^{12}$ This definition follows previous studies in the ownership literature (e.g., La Porta et al., 1999; Claessens et al., 2000; Lin et al., 2012). By definition, the control-ownership wedge equals zero for widely held firms. Alternatively, using the ratio of control rights to cash-flow rights to capture the control-ownership divergence produces robust results.
} 
consequently, the greater the incentives of the controlling shareholders are to engage in tunneling and other moral hazard activities (Shleifer and Vishny, 1997; Johnson et al., 2000).

\subsection{Debt structure}

For each sample firm, Capital IQ reports its total debt as well as the types of debt and the amount for each type. Total debt is the sum of all types of debt, including term loans, revolving credit, senior bonds and notes, subordinated bonds and notes, commercial paper, capital leases, and other debt.

To study the choice between bank debt and public debt, we use the debt structure information from Capital IQ to construct two measures: the ratio of bank debt to total debt and the ratio of public debt to total debt. Bank debt is defined as the sum of term loans and revolving credit, and public debt is defined as the sum of senior bonds and notes, subordinated bonds and notes, and commercial papers. These two measures allow us to assess the importance of bank debt and public debt, respectively, in a firm's debt financing. ${ }^{13}$ Our results are robust to excluding capital leases and other debt from total debt when constructing these measures. Variations in the bank debt ratio come from both across countries and within country, with a cross-country standard deviation of 0.065 and a within-country standard deviation of 0.355 . The ratio of public debt to total debt has a cross-country standard deviation of 0.058 and a withincountry standard deviation of $0.258 .^{14}$ These statistics indicate the potential importance of within-country factors, such as firm ownership structure, in determining debt choice.

\footnotetext{
${ }^{13}$ As an alternative way to capture the mix of bank and public debt in a firm's debt structure, we also calculate the ratio of public debt to bank debt for all sample firms with nonzero bank debt. All three measures of debt choice produce highly robust and consistent results in all of our empirical analyses. For brevity, we only report the empirical results based on the bank debt ratio. Results based on the other measures are not tabulated in the paper but are available upon request.

${ }^{14}$ Following previous cross-country studies (e.g., Beck et al., 2000), we calculate the cross-country standard deviation from country averages and the within-country standard deviation using the deviations from country averages. Approximately $50 \%$ of firms in our sample do not rely on public debt financing.
} 
In addition to debt source, we also explore the impact of the control-ownership wedge on two other aspects of debt structure: debt maturity and security. Following the literature (e.g., Johnson, 2003; Datta et al., 2005; Billett et al., 2007), we use two alternative variables to measure debt maturity: the proportion of total debt maturing in more than 3 years, and the proportion of total debt maturing in more than 5 years. Security is defined as the proportion of total debt secured by collateral.

\subsection{Control variables}

In examining the relation between corporate ownership structure and debt structure, we control for differences in various firm characteristics including firm size, leverage, profitability, $Q$, asset tangibility, and default risk. ${ }^{15}$ To account for possible differences and changes in the reliance on a particular type of debt through time and across industries and countries, we also control for year, industry (based on the Fama-French 48-industry classification), and country fixed effects in our analyses.

Table 1A provides the detailed definitions for all of the variables used in the paper, and Table 1B reports summary statistics for the sample. The descriptive statistics for the debt structure and ownership structure variables are largely in line with the previous literature (e.g., Houston and James, 1996; Laeven and Levine, 2008).

[Insert Tables 1A and 1B here]

\section{Results}

\subsection{The effect of corporate ownership structure on the choice of debt source} levels.

${ }^{15}$ To avoid potential problems with outliers, all variables in the paper are winsorized at the $0.5 \%$ and $99.5 \%$ 
In this section, we investigate the relation between a firm's ownership structure and its choice of debt. Before conducting regression analyses, to get a visual sense about the relation between control-ownership divergence and debt choice, we first construct country-by-country scatter plots, with the control-ownership wedge on the $x$-axis and the ratio of bank debt to total debt on the $y$-axis (Figure 1). In these plots, we can observe a clear, negative relation between control-ownership divergence and bank debt reliance. This strong relationship is consistent across countries and does not appear to be driven by outliers. ${ }^{16}$

\section{[Insert Figure 1 here]}

We then examine the relation between ownership structure and debt choice using multivariate analysis. We estimate the following regression model:

Debt choice measure $=f($ Control-ownership wedge, Firm controls, Year, industry, and

$$
\text { country effects). }
$$

In the regression, the dependent variable is a debt choice measure, capturing a firm's reliance on bank debt or public debt in its debt financing. The key independent variable is the control-ownership wedge, which captures the degree of the separation of ownership and control in the firm's ownership structure. We control for the cash-flow rights of the largest ultimate owner as well as a set of other firm characteristics that may influence the choice of debt source. In addition, we include year, industry, and country fixed effects.

The regression results of estimating Equation (1) are reported in Table 2. The dependent variable is the ratio of bank debt to total debt. We run three specifications. The first two are ordinary least squares (OLS) regressions. Following Houston and James (1996), we also estimate a third specification in which we estimate Tobit regressions, because the dependent

\footnotetext{
${ }^{16}$ We also compare the debt composition between firms at the top of pyramids and firms at the bottom of pyramids. Consistently, we find that firms at the top of pyramids rely more on bank debt financing than firms at the bottom of pyramids. The proportion of bank debt in total debt is approximately $20 \%$ higher for firms at the top of pyramids than for firms at the bottom of pyramids. In contrast, firms at the bottom of pyramids have approximately $30 \%$ more public debt in their debt composition compared to firms at the top of pyramids.
} 
variables are proportions and are thus constrained. ${ }^{17}$ We include industry fixed effects and country $\times$ year fixed effects in all specifications. ${ }^{18}$ Standard errors are clustered at the firm level and are heteroskedasticity-robust.

\section{[Insert Table 2 here]}

The results in Table 2 show that there is a negative and significant relationship between the proportion of bank financing in a firm's debt structure and the degree of the separation of ownership and control in the firm's ownership structure. The coefficient on the controlownership wedge is negative and statistically significant across all specifications. Based on the estimates from Column 2, a one-standard-deviation increase in the control-ownership wedge reduces the ratio of bank debt to total debt by more than 16 percentage points, everything else equal. This effect is also economically significant given the sample average bank debt to total debt ratio of $71 \%$.

In contrast, we find that the control-ownership divergence is positively related to the proportion of public debt (unreported but available upon request). In a specification similar to Column 2 but with the ratio of public debt to total debt as the dependent variable, we find that a one-standard-deviation increase in the control-ownership wedge increases the ratio of public debt to total debt by 2.9 percentage points, representing a $20 \%$ increase over the sample average public debt to total debt ratio of $15 \%$.

Regarding the control variables, we find that larger firms, more profitable firms, firms with higher leverage, and firms with higher asset tangibility tend to rely less on bank debt and more on public debt. These findings are consistent with those reported in previous studies (e.g., Houston and James, 1996; Denis and Mihov, 2003).

\footnotetext{
${ }^{17}$ Specifically, we run pooled Tobit regressions (Wooldridge, 2002) and report the estimated marginal effects.

${ }^{18}$ We have also run specifications with year, industry, and country fixed effects as well as specifications with country fixed effects and industry $\times$ year fixed effects and obtained qualitatively and quantitatively similar results for all of our empirical analyses. For brevity, these results are not reported but are available upon request.
} 
Overall, these results indicate that firms with wider divergences between controlling shareholders' cash-flow rights and control rights tend to rely more heavily on public debt financing and less on bank debt financing. As a firm's control-ownership wedge increases, the proportion of bank debt in the firm's debt financing decreases while the firm's reliance on public debt increases. The relationship between a firm's control-ownership divergence and its choice between bank debt and public debt is consistent with the hypothesis that firms controlled by large shareholders with excess control rights choose public debt financing over bank debt as a way of avoiding scrutiny and insulating themselves from bank monitoring.

\subsection{Sharper tests of the monitoring avoidance hypothesis}

The positive link between a firm's control-ownership wedge and its reliance on public debt in place of bank debt is consistent with the prediction of the monitoring avoidance hypothesis. In this section, we further test the monitoring avoidance hypothesis by exploring whether the effect of the control-ownership wedge on firm debt choice is influenced by factors that affect the dominant shareholder's incentive to elude monitoring. The monitoring avoidance hypothesis predicts that the negative relationship between a firm's control-ownership wedge and its reliance on bank debt should be particularly strong in situations where the control-ownership divergence is more likely to result in intensive monitoring from banks. Similarly, the monitoring avoidance effect should also be more pronounced in the presence of factors that heighten the dominant shareholder's tunneling incentives and, as a consequence, the incentive to avoid bank monitoring. Conversely, factors that reduce the tunneling incentives and thus the monitoring avoidance incentives of the controlling shareholder should weaken the effect of the control-ownership wedge on bank debt reliance.

The factors that we examine include financial distress risk, information opacity, family ownership, the presence of multiple large shareholders, and the strength of shareholder rights. 
Empirically, we implement these finer tests by augmenting our baseline model to include the factor under study and its interaction with the control-ownership wedge. In addition to providing further evidence on the monitoring avoidance hypothesis, examining the interaction effects help to shed light on the channels through which tunneling incentives and the ensuing incentives to elude monitoring induced by the separation of ownership and control can be mitigated or exacerbated.

\subsubsection{Financial distress risk}

As Jensen and Meckling (1976) and others have noted, when firms are in financial distress, asset substitution and moral hazard issues become particularly strong concerns to creditors. As a consequence, banks are more likely to impose intensive and strict monitoring over firms with high financial distress risk (e.g., Campello et al., 2011). At the same time, empirical evidence suggests that controlling shareholders' tunneling incentives are heightened during financial distress, resulting in rampant moral hazard activities in distressed firms with divergence between ownership and control (e.g., Johnson et al., 2000). Therefore, when firms have high financial distress risk, large shareholders with excess control rights have particularly strong incentives to avoid bank monitoring, which would make tunneling more difficult, and to rely instead on public debt financing. In other words, we expect firm financial distress risk to accentuate the link between the control-ownership wedge and firm debt choice.

We use two alternative variables to measure a firm's financial distress risk. Z-score (Altman, 1968) is an accounting-based measure that captures the financial health of a company, and Distance to default (Crosbie and Bohn, 2003) is a market-based measure that estimates the likelihood that the market value of a firm's assets will stay above its debt default threshold. ${ }^{19}$

\footnotetext{
${ }^{19}$ Specifically, Distance to default is calculated as the difference between the estimated market value of assets and the debt default threshold, divided by the product of the market value of assets and asset volatility. The detailed definitions and estimation methodologies for Z-score and Distance to default are reported in Table 1A.
} 
For both measures, higher values indicate better financial health and lower financial distress and default risk. Table 3 presents the regression results for models including the financial distress risk measure and its interaction with the control-ownership wedge. The dependent variable is the ratio of bank debt to total debt.

[Insert Table 3 here]

As can be seen from the table, Z-score and Distance to default are negatively and significantly related to the ratio of bank debt to total debt. These effects are consistent with the existing evidence in the literature that firms with high distress risk tend to rely more on bank debt (e.g., Denis and Mihov, 2003), since bank debt financing is associated with higher renegotiation efficiency and re-contracting flexibility during financial distress (Gilson et al., 1990; Thakor and Wilson, 1995). More important, the interaction terms between the financial distress risk measures and the control-ownership wedge are consistently positive and significant. This indicates that the effect of ownership structure on bank debt reliance is weaker in firms with better financial health. The results in Table 3 suggest that monitoring avoidance incentives induced by the control-ownership divergence are more powerful in financially distressed firms, resulting in a more pronounced effect of the control-ownership wedge on debt choice in these firms. $^{20}$

\subsubsection{Information Opacity}

The degree of information opacity of a firm may also affect its controlling shareholder's incentive to avoid bank monitoring. High information opacity lowers the costs and increases the likelihood of engaging in tunneling and other moral hazard activities by dominant shareholders

\footnotetext{
${ }^{20}$ An alternative, consistent way to interpret the interaction effects is that the control-ownership wedge weakens the link between a firm's financial distress risk and its reliance on bank debt because controlling shareholders with excess control rights have heightened incentives to avoid bank scrutiny and monitoring during financial distress.
} 
and, at the same time, banks are likely to impose stricter monitoring on borrowers with greater information opacity (e.g., Lin et al., 2012). In anticipation of the intensive monitoring from banks, opaque firms controlled by large shareholders with excess control rights have particularly strong incentives to rely more on public debt and less on bank debt in order to avoid bank scrutiny. Therefore, the effect of the control-ownership wedge on bank debt reliance should be more pronounced for informationally opaque firms.

To empirically assess how information opacity affects the link between ownership structure and debt choice, we use multiple measures to proxy for the degree of firm information opacity. These include firm size, inclusion in a major national stock index, analyst coverage, and the volatility of accruals. ${ }^{21}$ Generally speaking, firms that are larger in size, that are part of major stock indices, that are widely followed by analysts, and that have less volatile accruals tend to be more transparent and have lower levels of information asymmetry.

Table 4 reports the estimates for regressions including the information opacity measures and their interaction terms with the control-ownership wedge variable in our baseline model, with the ratio of bank debt to total debt as the dependent variable.

[Insert Table 4 here]

Consistent with the existing literature, the coefficients on the information opacity proxies in Table 4 indicate that opaque firms tend to rely more on bank debt. This suggests that banks possess comparative advantages over public investors in producing information (Fama, 1985) and pricing claims that are hard to value (Hadlock and James, 2002) when faced with high levels of information asymmetry. It is more interesting, however, that the interaction effects indicate that information opacity indeed strengthens the relation between ownership structure and debt choice. As can be seen from the estimates in Table 4, the effect of the control-ownership wedge on bank debt reliance is less pronounced for larger firms, firms included in major stock indices,

\footnotetext{
${ }^{21}$ We estimate the volatility of accruals following the methodology in Dechow and Dichev (2002) and McNichols (2002). The detailed definitions of the information opacity proxies are reported in Table 1A.
} 
and firms followed by more analysts, and is more pronounced for firms with more volatile accruals. Overall, these results support the monitoring avoidance hypothesis and indicate that the preference for public debt over bank debt at firms dominated by large shareholders with excess control rights is intensified by information opacity. ${ }^{22}$

\subsubsection{Family ownership}

Next we examine the effect of the identity of the largest ultimate owner on the link between a firm's control-ownership divergence and its debt choice, focusing on family ownership. When a firm's controlling shareholder is a family or an individual, the tunneling incentives induced by the separation of ownership and control may be particularly strong because the private benefits of control are not diluted among many unrelated investors (Villalonga and Amit, 2006). As a consequence, family-controlled firms might have sharpened incentives to avoid bank monitoring. Empirically, this means that the effect of the control-ownership divergence on firm debt choice should be greater for family-controlled firms.

\section{[Insert Table 5 here]}

Table 5 reports the results of this investigation. We define a dummy variable, Family ownership, that equals one if the largest ultimate owner of the firm is a family or an individual and zero otherwise. The coefficient on the interaction between the family ownership dummy variable and the control-ownership wedge is significant at the $1 \%$ level and bears the same sign as the coefficient on the control-ownership wedge. This indicates that the control-ownership divergence has a more depressing effect on bank debt reliance (as measured by the ratio of bank debt to total debt) for family-controlled firms than for other firms. The estimates in Table 5 show that, everything else equal, the effect of the control-ownership wedge on firm debt choice

\footnotetext{
${ }^{22}$ Another consistent way to interpret the interaction results is that control-ownership divergence weakens the relation between information opacity and bank debt reliance due to controlling shareholders' incentives to avoid bank monitoring.
} 
is nearly twice as large in family-controlled firms as in other firms. Consistent with our expectation, family ownership indeed strengthens the relation between ownership structure and debt choice.

\subsubsection{The presence of multiple large shareholders}

Previous studies suggest that having multiple large shareholders enhances external monitoring (e.g., Maury and Pajuste, 2005). In particular, it is more difficult and less likely for the controlling shareholder to extract private benefits in the presence of another blockholder. Having other large owners, therefore, lowers the tunneling incentives of the controlling shareholder, and in turn, lowers his incentive to avoid bank monitoring. We thus expect the presence of multiple large shareholders to weaken the relation between control-ownership divergence and firm debt choice.

To test this conjecture, we define a dummy variable, Multiple large owners, which equals one if the firm has at least one other owner that has $10 \%$ or more of the voting rights besides the ultimate largest owner. Table 6 presents the results from estimating a regression that includes the Multiple large owners dummy and its interaction with the control-ownership wedge as additional independent variables.

\section{[Insert Table 9 here]}

The results in Table 9 show that, consistent with the bank monitoring avoidance hypothesis, the effects of control-ownership divergence on bank debt reliance are mitigated by the presence of multiple large owners. The coefficient on the interaction term between Multiple large owner and Control-ownership wedge is statistically significant and has the opposite sign of the coefficient on Control-ownership wedge. Ceteris paribus, having another large shareholder reduces the effect of the control-ownership wedge on the ratio of bank debt to total debt by approximately a third. 


\subsubsection{Shareholder rights}

A country's legal environment may also affect the relation between corporate ownership structure and firm debt choice. We focus on shareholder rights, which offer minority shareholders legal protection against controlling shareholders' potential expropriation activities. Strong shareholder rights protection reduces large shareholders' tunneling incentives and, consequently, reduces their incentives to avoid bank monitoring. Therefore, the effect of control-ownership divergence on bank debt reliance should be smaller for firms in countries with better shareholder rights protection.

We use the Anti-self-dealing index and the Anti-director index as proxies for the level of shareholder rights protection in a country (Djankov et al., 2008; La Porta et al., 1998). Higher index values indicate higher levels of investor protection against self-dealing by controlling shareholders and corporate insiders. ${ }^{23}$ We include these shareholder rights measures and their respective interactions with the control-ownership wedge in our baseline model and report the regression results in Table 7.

\section{[Insert Table 7 here]}

Consistent with our expectation, shareholder rights protection has a significant moderating effect on the relation between control-ownership divergence and debt choice. The controlownership wedge has a more depressing effect on bank debt reliance for firms in countries with weaker shareholder rights (lower index values). These results highlight the importance of law and institutions in alleviating moral hazard problems and mitigating the distortions in firm financing choices caused by controlling shareholders' tunneling incentives.

\subsection{Robustness}

\footnotetext{
${ }^{23}$ Detailed definitions of the indices are provided in Table $1 \mathrm{~A}$.
} 


\subsubsection{Propping}

Our analyses so far focus on controlling shareholders' tunneling and monitoring avoidance incentives in explaining firm debt choice. However, controlling shareholders' propping incentives may also affect borrowing firms' reliance on bank debt versus public debt. Specifically, controlling shareholders in an ownership chain may have incentives to prop up a financially distressed firm to preserve their options to expropriate funds from the firm in the future (Friedman et al., 2003). Propping is carried out mainly through capital and resource transfers from other firms under the controlling shareholders' control, normally from firms in which the controlling shareholders have low cash-flow rights (i.e., firms low down in the ownership chain) to firms in which they have high cash-flow rights (i.e., firms high up in the ownership chain) (Bertrand et al., 2002). In such cases, firms with controlling shareholders may find the benefits associated with bank debt financing such as renegotiation efficiency and recontracting flexibility during financial distress (e.g., Gilson et al., 1990; Denis and Mihov, 2003) less valuable, and as a result, find bank debt less attractive.

To take the propping incentives into consideration and check the robustness of our main results, we follow the recent ownership literature (Lin et al., 2011) and construct two measures to proxy for a borrowing firm's potential of being propped up. Intuitively, these measures estimate the assets that could potentially be used to prop the firm up. For each borrowing firm, the first measure is calculated as the total value of assets of all firms that are positioned underneath the firm in the ownership chain, scaled by the firm's assets. Alternatively, we construct a second, more conservative measure by calculating the weighted sum of the asset values of all firms lower down in the ownership chain (scaled by the borrowing firm's assets). The weight for each firm beneath the borrowing firm is the ultimate controlling shareholder's control rights in that firm. Using these propping measures and focusing on the sample of firms belonging to pyramids, we 
test whether our main results continue to hold within pyramids after controlling for potential propping. The empirical results are presented in Table 8 .

[Insert Table 8 here]

In Columns 1 and 2, we control for a borrowing firm's potential of being propped up in our baseline regression with the bank debt ratio as the dependent variable, using the first propping measure in Column 1 and the second propping measure in Column 2. We find that the coefficients on the propping measures are significantly negative, suggesting that the potential of being propped up does make bank debt financing less attractive to borrowing firms. The effect of the control-ownership wedge on bank debt reliance, however, remains economically and statistically significant after controlling for potential propping. The coefficients on the controlownership wedge are significant at the $1 \%$ level in both columns and are of similar magnitudes as in the baseline regressions in Table 2.

Alternatively, we split the pyramid sample into firms with positive propping potentials and firms without propping potentials based on the propping measures and repeat the baseline regressions in the two subsamples. These results are reported in Columns 3 and 4 of Table 8 . In each subsample, we continue to find that the control-ownership wedge exerts a negative and statistically significant impact on bank debt reliance, suggesting that our results are highly robust even in the subsample of firms that likely have no potential of being propped up. The effect of the wedge is stronger in the subsample of firms without propping potentials. This suggests that in anticipation of more intensive bank monitoring due to the lack of propping potentials, these firms have stronger monitoring avoidance incentives in deciding their debt choice. In another set of tests (unreported for brevity but available upon request), we exclude firms with no controlling shareholders and focus only on firms that have controlling shareholders. Intuitively, all the firms in this subsample are subject to potential propping, and we want to explore whether the controlownership divergence still has any explanatory power for debt choice for this group of firms. We find that the control-ownership wedge continues to exert a significantly negative impact on 
bank debt reliance in the subsample. Overall, these results show that our main finding remains highly robust after accounting for the potential propping incentives of the controlling shareholders.

\subsubsection{Level of Bank Debt}

In this subsection we examine whether the level of existing bank debt in a firm's debt structure affects the link between control-ownership divergence and bank debt reliance. From

the bank's perspective, an increase in financial stake or credit exposure to the borrower generally enhances monitoring incentives (Sufi, 2007). However, it is possible that for firms already with high levels of bank debt, the change in bank monitoring may not be very sensitive to the change in ownership structure because high-bank debt firms are already subject to strict bank monitoring. As a result, the link between control-ownership divergence and bank debt reliance may weaken as bank debt accumulates to the level beyond which banks' incremental monitoring incentives diminish. To test this hypothesis, we split our sample into two groups based on the sample median bank debt-to-total debt ratio and repeat the baseline regression in each subsample. The results are reported in Table 9.

\section{[Insert Table 9 here]}

As can be seen from the table, the control-ownership wedge has a weaker effect on debt choice when the borrowing firm has a high bank debt ratio (Column 1). The differences in the corresponding coefficients on the control-ownership wedge between the two subsamples are statistically significant at the $1 \%$ level. Alternatively, we split the sample into firms with a bank debt ratio greater than $50 \%$ and firms with a bank debt ratio less than or equal to $50 \%$ and also find consistent results in the subsamples thus constructed. For brevity, these results are not tabulated but are available from the authors. 


\subsubsection{Endogeneity of corporate ownership structure}

Our baseline results are consistent with the monitoring avoidance hypothesis but they are subject to the criticism that some unobserved, omitted factor may affect both a firm's ownership structure and its debt choice and thus bias the results. To alleviate this concern, our baseline regressions include country and industry fixed effects as well as the year interaction (e.g., country $\times$ year) fixed effects to control for time-invariant and time-varying factors that may be driving the results. Moreover, the results from the interaction term tests help to alleviate this concern as the interaction effects elucidate the mechanisms through which corporate ownership structure affects debt choice and are less likely to be subject to endogeneity problems. In this subsection, we further address the endogeneity concerns using change regressions and instrumental variable regressions.

First, we use change regressions to examine the effect of a change in a firm's controlownership wedge on the change in the firm's debt choice. If the firm-specific omitted characteristics that jointly affect ownership structure and debt choice are constant over time, focusing on changes controls for such time-invariant factors. Table 10 presents the change regression results. To be retained in the sample for the change regressions, a firm must have at least two firm-year observations in the sample for us to calculate the change variables and must have a nonzero change in its control-ownership wedge between the two periods. The dependent variable in Table 10 is the change in the ratio of bank debt to total debt of the borrowing firm. The key independent variable is the change in the firm's control-ownership wedge.

[Insert Table 10 here]

The regression estimates in Table 10 corroborate our baseline results. Controlling for changes in other firm characteristics, the change in the control-ownership wedge of a firm's largest owner is positively related to the change in the proportion of public debt in the firm's 
debt structure but negatively related to the change in the proportion of bank financing in total debt. All of the effects remain statistically significant at the $1 \%$ level.

We also estimate instrumental variable regressions. In these regressions we instrument for each firm's ownership structure using the initial industry average ownership structure in the firm's country. Previous studies (e.g., Laeven and Levine, 2009; Lin et al., 2012) suggest that the initial average ownership structure in a firm's industry is a reasonable instrument for the firm's ownership structure, because an individual firm's ownership structure is correlated with its industry average but it is unlikely that an individual firm's current debt choice is directly driven by the historical industry average ownership structure other than through its effect on the firm's own ownership structure. Specifically, for each sample firm, we calculate the average cash-flow rights and average control-ownership wedge for all of the other firms in the same country and industry as the firm at the beginning of the sample. We use these initial countryspecific industry averages as instruments for the firm's cash-flow rights and control-ownership wedge, respectively. Table 11 presents the regression results from the instrumental variable estimation.

\section{[Insert Table 11 here]}

The results in Table 11 confirm that a firm's control-ownership wedge significantly affects its choice of debt. As the control-ownership wedge increases, the firm chooses to rely less on bank debt in its debt financing. ${ }^{24}$ The coefficients on the control-ownership wedge are consistently significant at the $1 \%$ level across specifications, and their magnitudes are larger (in absolute value terms) compared to the corresponding estimates from the baseline OLS regressions. In summary, after accounting for the potential issue of endogeneity using different approaches, we find that corporate ownership structure continues to have a statistically and economically significant impact on firm debt choice.

\footnotetext{
${ }^{24}$ The instruments enter the first-stage regressions significantly at the $1 \%$ level, and the F-test of excluded instruments confirms that the instruments are valid. The details are available upon request.
} 


\subsubsection{Additional robustness tests}

We undertake several additional robustness tests to ensure that our findings are not driven by outliers or any specific country. First, we test whether our regression results are driven by any specific country by replicating our main results in Table 2 omitting each country one at a time. We also re-estimate the baseline regression in the subsample of Asian countries and in the subsample of European countries. Additionally, we drop the 51 country-industry pairs in our sample with fewer than 10 observations and test the robustness of the results. We find that our results are highly robust in all of the above tests. The results of these robustness tests are not presented in the paper but are available from the authors upon request.

\subsection{Other aspects of debt structure: maturity and security}

We have shown that the tunneling and monitoring avoidance incentives of the controlling shareholders induced by the divergence between ownership and control exert a significant impact on borrowing firms' choice of debt source. These incentives may also affect other aspects of debt structure. In this section, we investigate the effect of control-ownership divergence on debt maturity and debt security.

As shown in the banking literature, both short debt maturity and high collateral requirements increase banks' monitoring incentives and enhance monitoring intensity (Rajan and Winton, 1995; Park, 2000; Stulz, 2000; Datta et al., 2005). In anticipation of the heightened scrutiny induced by short maturity and high security requirements, firms controlled by large shareholders with excess control rights would choose a debt structure with long maturity and low levels of collateralization as a way of avoiding monitoring (Datta et al., 2005). Moreover, bank debt tends 
to have a much shorter maturity than public debt ${ }^{25}$ and is more often secured by collateral ${ }^{26}$. Given our main finding that borrowing firms with larger control-ownership wedges rely more on public debt in place of bank debt, we would also expect the wedge to be positively associated with maturity and negatively associated with security.

We present the results of our investigation in Table 12. We focus on debt maturity in Columns 1 and 2. The dependent variables are the proportion of total debt maturing in more than 3 years in Column 1 and the proportion of total debt maturing in more than 5 years in Column 2 . In Column 3, we examine debt security using the proportion of total debt secured by collateral as the dependent variable.

\section{[Insert Table 12 here]}

As can be seen from the OLS regression estimates in Table 12, the control-ownership wedge has a significantly positive impact on debt maturity and a significantly negative impact on debt security. Using the estimates from Column 2, everything else equal, a one-standard-deviation increase in the control-ownership wedge is associated with an increase of $2.5 \%$ in the proportion of long-maturity debt in total debt, representing an $11 \%$ increase over the sample average longmaturity (5+ years) debt proportion $(22.3 \%)$. In contrast, a one-standard-deviation increase in the wedge is associated with a decrease in the debt collateralization ratio by $12 \%$ of the sample mean. In short, the effects of the control-ownership divergence on debt maturity and security are significant both economically and statistically. They are consistent with the monitoring avoidance hypothesis and corroborate our findings on debt source.

\section{Conclusion}

${ }^{25}$ See, e.g., Tufano (1993), Stoh and Mauer (1996), Johnson (1997), and Park (2000). For instance, Johnson (1997) finds that debt maturity (measured by the proportion of debt maturing in more than three years) is significantly longer for firms using predominantly public debt than for firms using predominantly bank debt.

${ }^{26}$ See, e.g., Gilson and Warner (2000). In our sample, secured bank debt represents $32 \%$ of total bank debt while secured public debt represents only $11 \%$ of the total public debt. 
There is rich empirical evidence suggesting that the divergence between ownership and control creates strong incentives for large shareholders to engage in tunneling and other moral hazard activities. Yet little is known about how such incentives and activities induced by dominant shareholders' excess control rights affect firm financing behavior. The aim of this paper is to enhance our knowledge of these matters by examining the choice of debt source by firms with control-ownership divergences. Compared to public bondholders, banks can serve as more effective monitors in deterring potential self-dealing activities because of their concentrated holdings, strong bargaining power, and superior access to information. As a consequence, firms controlled by large shareholders with excess control rights and hence strong tunneling incentives may prefer public debt financing over bank debt as a way to evade scrutiny and insulate themselves from bank monitoring.

Our paper examines this bank monitoring avoidance hypothesis using a novel, handcollected data set on corporate ownership, control and debt structures for 9,831 firms in 20 countries from 2001 to 2010 . We find strong evidence that the monitoring avoidance incentives induced by the separation of ownership and control exert a significant impact on the choice between bank debt and public debt. Specifically, we find that the divergence between the control rights and cash-flow rights of a borrowing firm's controlling shareholder decreases its reliance on bank debt financing and increases its reliance on public debt financing significantly. These effects are particularly pronounced for family-controlled firms, informationally opaque firms, and firms with high financial distress risk, and are weakened by the presence of multiple large owners and strong shareholder rights. We also find that the control-ownership divergence of a borrowing firm's dominant shareholder increases the firm's debt maturity and decreases its debt collateralization significantly. Collectively, our results identify ownership structure as an important determinant of firm debt structure and shed new light on a channel through which the 
control-ownership divergence and the ensuing moral hazard incentives influence firm financial decisions. 


\section{References}

Altman, E., 1968. Financial ratios, discriminant analysis, and the prediction of corporate bankruptcy. Journal of Finance 23, 589-609.

Beck, T., Levine, R., Loayza, N., 2000. Finance and the sources of growth. Journal of Financial Economics 58, 261-300.

Bertrand, M., Mehta, P., Mullainathan, S., 2002. Ferreting out tunneling: an application to Indian business groups. Quarterly Journal of Economics 117, 121-148.

Billett, M., King, T., Mauer, D., 2007. Growth opportunities and the choice of leverage, debt maturity, and covenants. Journal of Finance 62, 697-730.

Campello, M., Lin, C., Ma, Y., Zou, H., 2011. The real and financial implications of corporate hedging. Journal of Finance 66, 1615-1648.

Chui, M., Domanski, D., Kugler, P., Shek, J., 2010. The collapse of international bank finance during the crisis: Evidence from syndicated loan markets. BIS Quarterly Review, September 2010, 39-49.

Claessens, S., Djankov, S., Lang, L. H. P., 2000. The separation of ownership and control in East Asian corporations. Journal of Financial Economics 58, 81-112.

Crosbie, P. J., Bohn, J., 2003. Modeling default risk. Moody’s KMV.

Datta, S., Iskandar-Datta, M., Raman, K., 2005. Managerial stock ownership and the maturity structure of corporate debt. Journal of Finance 60, 2333-2350.

Dechow, P. M., Dichev, I. D., 2002. The quality of accruals and earnings: the role of accrual estimation errors. The Accounting Review 77, 35-59.

Denis, D., Mihov, V., 2003. The choice among bank debt, non-bank private debt, and public debt: evidence from new corporate borrowings. Journal of Financial Economics 70, 3-28.

Diamond, D., 1984. Financial intermediation and delegated monitoring. Review of Economic Studies 51, 393-414.

Diamond, D., 1991. Monitoring and reputation: the choice between bank loans and directly placed debt. Journal of Political Economy 99, 689-721.

Djankov, S., La Porta, R., López-de-Silanes, F., Shleifer, A., 2008. The law and economics of self-dealing. Journal of Financial Economics 88, 430-465. 
Faccio, M., Lang, H.P., 2002. The ultimate ownership of Western European corporations. Journal of Financial Economics 65, 365-395.

Fama, E., 1985. What's different about banks? Journal of Monetary Economics 15, 29-39.

Friedman, E., Johnson, S., Mitton, T., 2003. Propping and tunneling. Journal of Comparative Economics 31, 732-750.

Gilson, S., John, K., Lang, L., 1990. Troubled debt restructuring: an empirical study of private reorganization of firms in default. Journal of Financial Economics 27, 315-353.

Gilson, S. C., Warner J., 2000. Private versus public debt: evidence from firms that replace bank loans with junk bonds. Working paper, Harvard Business School.

Hadlock, C., James, C., 2002. Do banks provide financial slack? Journal of Finance 57, 13831419 .

Hoshi, T., Kashyap, A., Scharfstein, D., 1993. The choice between public and private debt: an analysis of post-deregulation corporate financing in Japan. NBER working paper.

Houston, J., James, C., 1996. Bank information monopolies and the mix of private and public debt claims. Journal of Finance 51, 1863-1889.

James, C., 1987. Some evidence on the uniqueness of bank loans. Journal of Financial Economics 19, 217-235.

Jensen, M., Meckling, W., 1976. Theory of the firm: managerial behavior, agency costs, and capital structure. Journal of Financial Economics 3, 305-360.

Johnson, S., 1997. An empirical analysis of the determinants of debt ownership structure. Journal of Financial and Quantitative Analysis 32, 47-69.

Johnson, S., 2003. Debt maturity and the effects of growth opportunities and liquidity risk on leverage. Review of Financial Studies 16, 209-236.

Johnson, S., La Porta, R., López-de-Silanes, F., Shleifer, A., 2000. Tunneling. American Economic Review 90, 22-27.

Kale, J., Meneghetti, C., 2010. The choice between public and private debt: a survey. Working paper, Georgia State University.

La Porta, R., López-de-Silanes, F., Shleifer, A., Vishny, R., 1998. Law and finance. Journal of Political Economy 106, 1113-1155.

La Porta, R., López-de-Silanes, F., Shleifer, A., 1999. Corporate ownership around the world. Journal of Finance 54, 471-517. 
Laeven, L., Levine, R., 2008. Complex ownership structures and corporate valuations. Review of Financial Studies 21, 579-604.

Laeven, L., Levine, R., 2009. Bank governance, regulation, and risk taking. Journal of Financial Economics 93, 259-275.

Lin, C., Ma, Y., Malatesta, P., Xuan, Y., 2012. Corporate ownership structure and bank loan syndicate structure. Journal of Financial Economics 104, 1-22.

Maury, B., Pajuste A., 2005. Multiple large shareholders and firm value. Journal of Banking and Finance 29, 1813-1834.

McNichols, M. F., 2002. The quality of accruals and earnings: discussion. The Accounting Review 77, 61-69.

Merton, R. C. 1974. On the pricing of corporate debt: the risk structure of interest rates. Journal of Finance 29, 449-470.

Park, C., 2000. Monitoring and structure of debt contracts. Journal of Finance 55, 2157-2195.

Rajan, R., 1992. Insiders and outsiders: the choice between informed and arm's length debt. Journal of Finance 47, 1367-1400.

Rajan, R., Winton, A., 1995. Covenants and collateral as incentives to monitor. Journal of Finance 50, 1113-1146.

Ramakrishnan, S., Thakor, A., 1984. Information reliability and a theory of financial intermediation. Review of Economic Studies 51, 415-432.

Shleifer, A., Vishny, R., 1997. A survey of corporate governance. Journal of Finance 52, 737783.

Stiglitz, J., Weiss, A., 1983. Incentive effects of terminations: applications to credit and labor markets. American Economic Review 73, 912-927.

Stohs, M. H., Mauer, D., 1996. The determinants of corporate debt maturity structure. Journal of Business 69, 279-312.

Stulz, R., 2000. Does financial structure matter for economic growth? A corporate finance perspective. Working paper, Ohio State University.

Sufi, A., 2007. Information asymmetry and financing arrangements: evidence from syndicated Loans, Journal of Finance 62, 629-668. 
Thakor, A., Wilson, P., 1995. Capital requirements, loan renegotiation and the borrower's choice of financing source. Journal of Banking and Finance 19, 693-711.

Tufano, P., 1993. Financing acquisitions in the late 1980s: sources and forms of capital, in Margaret M. Blair, ed.: The Deal Decade (Brookings Institution, Washington D.C.).

Villalonga, B., Amit, R., 2006. How do family ownership, control and management affect firm value? Journal of Financial Economics 80, 385-417.

Wooldridge, J., 2002. The Econometric Analysis of Cross Section and Panel Data. The MIT press, United States. 


\section{Figure 1}

The relation between bank debt and control-ownership wedge across countries

This figure presents country-by-country scatter plots of the control-ownership wedge on the $x$-axis and the ratio of bank debt to total debt on the $y$-axis. The solid line in each plot is the fitted bank debt-tototal debt ratio. For each sample firm, the control-ownership wedge and the bank debt-to-total debt ratio plotted are the average value of the firm's control-ownership wedge and the average value of the firm's bank debt-to-total debt ratio over the sample period, respectively.
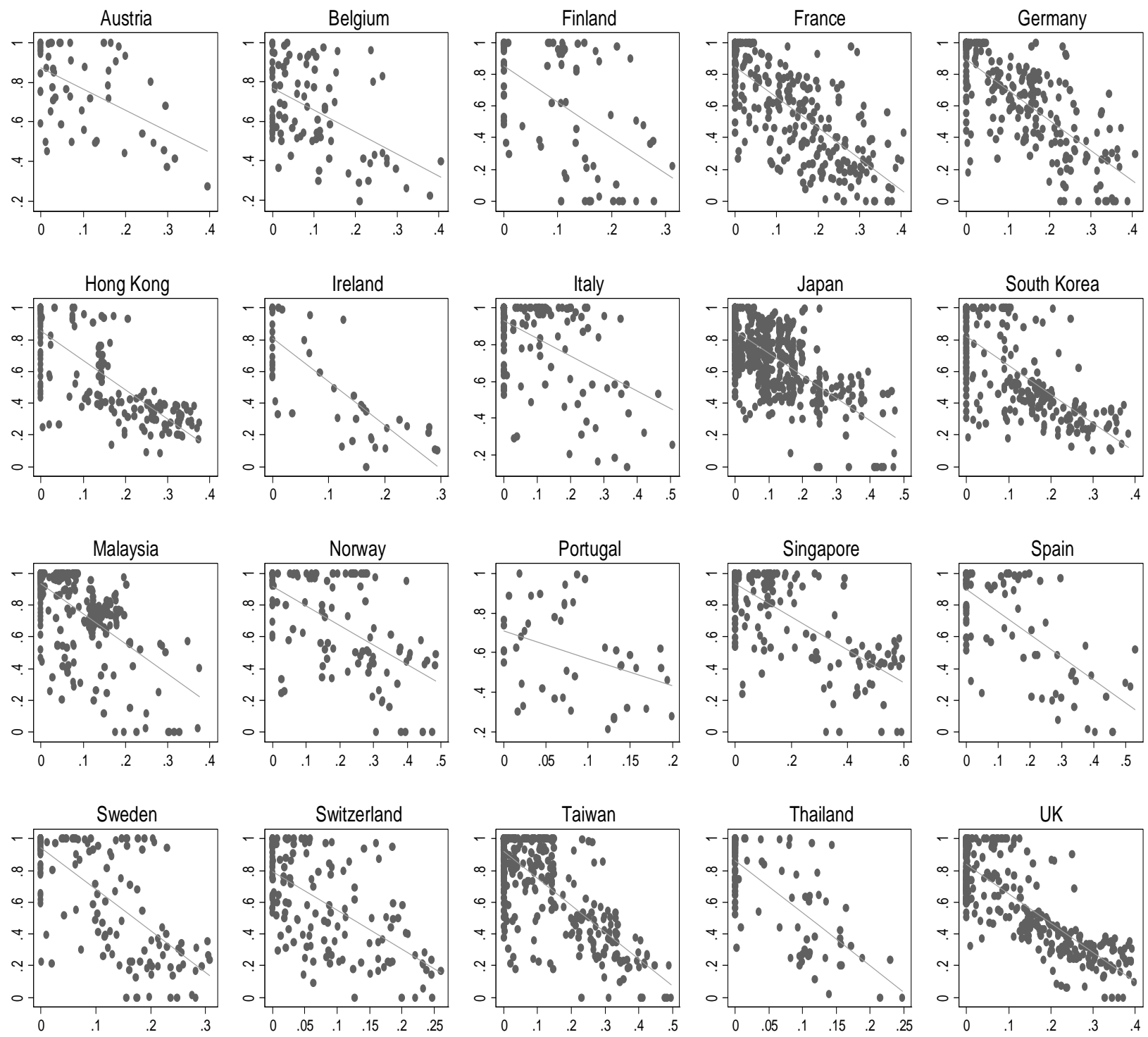


\section{Table 1A}

\section{Variable definitions}

This table provides definitions for all the variables used in the paper.

\begin{tabular}{ll}
\hline Variable name & Variable definition \\
\hline $\begin{array}{l}\text { Debt structure } \\
\text { Bank debt/Total debt }\end{array}$ & $\begin{array}{l}\text { The ratio of bank debt to total debt, calculated as the sum of term loans and } \\
\text { revolving credit divided by total debt } \\
\text { The ratio of public debt to total debt, calculated as the sum of senior bonds } \\
\text { and notes, subordinated bonds and notes, and commercial papers divided by } \\
\text { total debt } \\
\text { The ratio of long-term debt due after three (or five) years to total debt } \\
\text { Debt maturity }\end{array}$ \\
The ratio of total secured debt to total debt
\end{tabular}

Ownership structure

Control-ownership wedge

Cash-flow rights

Family ownership dummy

Multiple large owners dummy

\section{Firm characteristics}

Leverage

Tangibility

Log assets

Profitability

Q

Distance to default

Z-score

\section{(Continued on the next page)}

The difference between the control rights and cash-flow rights of the largest ultimate owner of the firm

The cash-flow rights of the largest ultimate owner of the firm

A dummy variable that equals one if the largest ultimate owner of the firm is a family or an individual and zero otherwise

A dummy variable that equals one if the firm has at least one other owner besides the ultimate largest owner that has $10 \%$ or more of the voting rights and zero otherwise

The sum of long-term debt and debt in current liabilities divided by total assets

Net property, plant, and equipment divided by total assets

The natural log of total assets measured in millions of U.S. dollars

EBITDA divided by total assets

The sum of market value of equity plus book value of debt divided by total assets, where market value of equity equals price per share times the total number of shares outstanding, and book value of debt equals total assets minus book value of equity

A market-based measure of default risk operationalized in Crosbie and Bohn (2003), calculated as $\left(\mathrm{V}_{\mathrm{a}}-\mathrm{D}\right) /\left(\mathrm{V}_{\mathrm{a}} \sigma_{\mathrm{a}}\right)$, where $\mathrm{V}_{\mathrm{a}}$ is market value of assets, $\mathrm{D}$ is debt in current liabilities plus one half of long-term debt, and $\sigma_{\mathrm{a}}$ is one-year asset volatility. The two unobservable variables, $\mathrm{V}_{\mathrm{a}}$ and $\sigma_{\mathrm{a}}$, are estimated by solving the following Merton (1974) pricing model for a one-year time horizon $(\mathrm{T}=1)$ using the market value of equity $\left(\mathrm{V}_{\mathrm{e}}\right)$, one-year equity volatility $\left(\sigma_{e}\right)$, debt $(D)$, and the three-month Treasury-bill rate $(r): V_{e}=$ $\mathrm{V}_{\mathrm{a}} \mathrm{N}\left(\mathrm{d}_{1}\right)-\mathrm{e}^{-\mathrm{r}} \mathrm{DN}\left(\mathrm{d}_{2}\right)$ and $\sigma_{\mathrm{e}}=\mathrm{N}\left(\mathrm{d}_{1}\right) \sigma_{\mathrm{a}} \mathrm{V}_{\mathrm{a}} / \mathrm{V}_{\mathrm{e}}$, where $\mathrm{d}_{1}=\left[\ln \left(\mathrm{V}_{\mathrm{a}} / \mathrm{D}\right)+\mathrm{r}+\right.$ $\left.0.5 \sigma_{\mathrm{a}}^{2}\right] / \sigma_{\mathrm{a}}$ and $\mathrm{d}_{2}=\mathrm{d}_{1}-\sigma_{\mathrm{a}}$.

Altman's (1968) Z-score, calculated as $(1.2 \times$ working capital $+1.4 \times$ retained earnings $+3.3 \times$ EBIT $+0.999 \times$ sales $) /$ total assets $+0.6 \times($ market value of equity/book value of debt) 


\section{Table 1A}

Variable definitions

(Continued)

\begin{tabular}{ll}
\hline Variable name & Variable definition \\
\hline Stock index inclusion dummy & $\begin{array}{l}\text { A dummy variable that equals one if the firm is included in a major national } \\
\text { stock index and zero otherwise }\end{array}$ \\
Number of analysts & The total number of stock analysts following the firm \\
Volatility of accruals & An empirical measure of accrual quality (Dechow and Dichev, 2002; \\
& McNichols, 2002), defined as the standard deviation of the firm-level \\
& residuals from a pooled OLS regression of the change in working capital on \\
past, present, and future operating cash flows, the change in sales, and the & level of property, plant, and equipment (all variables scaled by total assets) \\
The total value of the assets of all firms that are positioned below the \\
borrowing firm in the ownership chain, divided by the borrowing firm's total \\
assets (upper bound measure); or a weighted sum of the asset values of all \\
firms lower down in the ownership chain divided by the borrowing firm's \\
total assets, with the weight for each firm beneath the borrowing firm defined \\
as the ultimate controlling shareholder's control rights in that firm \\
(conservative measure)
\end{tabular}

Other

Anti-self-dealing

An index compiled by Djankov et al. (2008) with the help of Lex Mundi law firms that measures legal protection of minority shareholders against selfdealing, with higher values indicating stronger protection

Anti-director

An index compiled by La Porta et al. (1998) and Djankov et al. (2008) aggregating shareholder rights concerning voting and minority protection. The index ranges from 0 to 6 , with higher values indicating stronger protection of minority shareholders against insider expropriation. 


\section{Table 1B}

Summary statistics

This table reports the mean, standard deviation (STD), and number of observations $(N)$ for all the variables used in the paper. Definitions of all the variables are provided in Table 1A.

\begin{tabular}{|c|c|c|c|}
\hline Variable names & Mean & STD & $N$ \\
\hline \multicolumn{4}{|l|}{ Debt structure } \\
\hline Bank debt/Total debt & 0.714 & 0.361 & 43,502 \\
\hline Public debt/Total debt & 0.148 & 0.271 & 43,502 \\
\hline Debt maturity (due after 3 years) & 0.382 & 0.313 & 42,961 \\
\hline Debt maturity (due after 5 years) & 0.223 & 0.267 & 42,961 \\
\hline Debt security & 0.336 & 0.399 & 42,961 \\
\hline \multicolumn{4}{|l|}{ Ownership structure } \\
\hline Control-ownership wedge & 0.042 & 0.077 & 43,502 \\
\hline Cash-flow rights & 0.214 & 0.218 & 43,502 \\
\hline Family ownership dummy & 0.278 & 0.448 & 43,502 \\
\hline Multiple large owner dummy & 0.298 & 0.457 & 43,502 \\
\hline \multicolumn{4}{|l|}{ Firm characteristics } \\
\hline Leverage & 0.239 & 0.182 & 43,502 \\
\hline Tangibility & 0.401 & 0.241 & 43,502 \\
\hline Log assets & 5.221 & 1.940 & 43,502 \\
\hline Profitability & 0.077 & 0.119 & 43,502 \\
\hline$Q$ & 1.233 & 0.764 & 43,502 \\
\hline Distance to default & 2.355 & 3.011 & 43,502 \\
\hline Z-score & 2.637 & 2.347 & 43,273 \\
\hline Stock index inclusion dummy & 0.076 & 0.265 & 43,502 \\
\hline Number of analysts & 5.240 & 9.007 & 43,502 \\
\hline Volatility of accruals & 0.133 & 0.121 & 41,169 \\
\hline Propping potential (upper bound) & 0.533 & 0.815 & 43,502 \\
\hline Propping potential (conservative) & 0.073 & 0.161 & 43,502 \\
\hline \multicolumn{4}{|l|}{ Other } \\
\hline Anti-director & 3.927 & 0.820 & 43,502 \\
\hline Anti-self-dealing & 0.553 & 0.216 & 43,502 \\
\hline
\end{tabular}




\section{Table 2}

The effect of control-ownership wedge on the choice of debt source

This table presents regression results on the effect of the control-ownership wedge on the choice of debt source. The dependent variable is the ratio of bank debt to total debt. We estimate ordinary least squares (OLS) regressions in Columns 1 and 2 and a Tobit regression in Column 3 (marginal effects reported). The control-ownership wedge is defined as the difference between the control rights and cashflow rights of the largest ultimate owner of the firm. Definitions of all the other variables are reported in Table 1A. Robust standard errors clustered by firm are reported in parentheses. Significance at the 10\%, $5 \%$, and $1 \%$ level is indicated by $* * *$, and $* * *$, respectively.

\begin{tabular}{llll}
\hline & $(1)$ & $(2)$ & $(3)$ \\
\cline { 2 - 4 } & OLS & OLS & Tobit \\
\hline Control-ownership wedge & -2.187 & -2.104 & -2.164 \\
Cash-flow rights & $(0.447)^{* * *}$ & $(0.681)^{* * *}$ & $(1.015)^{* *}$ \\
Leverage & 0.051 & 0.042 & 0.044 \\
& $(0.043)$ & $(0.040)$ & $(0.047)$ \\
Tangibility & & -0.061 & -0.087 \\
& & $(0.025)^{* *}$ & $(0.037)^{* *}$ \\
Log assets & & -0.055 & -0.072 \\
& & $(0.037)$ & $(0.047)$ \\
Profitability & & -0.034 & -0.033 \\
& & $(0.015)^{* *}$ & $(0.014)^{* *}$ \\
Q & & -0.002 & -0.004 \\
Distance to default & & $(0.001)^{* *}$ & $(0.002)^{*}$ \\
& & -0.037 & -0.042 \\
Industry effects & & $(0.017)^{* *}$ & $(0.017)^{* *}$ \\
Country $\times$ Time effects & & -0.024 & -0.022 \\
Number of observations & Yes & $(0.010)^{* *}$ & $(0.009)^{* *}$ \\
Number of firms & 43,502 & Yes & Yes \\
Adjusted $R^{2}$ & 9,831 & 43,502 & Yes \\
Pseudo $R^{2}$ & 0.094 & 0.831 & 43,502 \\
\hline
\end{tabular}




\section{Table 3}

Financial distress risk and the effect of the control-ownership wedge on debt choice

This table presents regression results on the effect of firm financial distress risk on the relation between the control-ownership wedge and debt choice. The dependent variable is the ratio of bank debt to total debt. The control-ownership wedge is defined as the difference between the control rights and cash-flow rights of the largest ultimate owner of the firm. Z-score (Altman, 1968) is an accounting-based measure that captures the financial health of a company. Distance to default (Crosbie and Bohn, 2003) is a market-based measure that estimates the likelihood that the market value of a firm's assets will stay above its debt default threshold. Detailed definitions of all the variables are reported in Table 1A. Robust standard errors clustered by firm are reported in parentheses. Significance at the $10 \%, 5 \%$, and $1 \%$ level is indicated by $* * *$, and $* * *$, respectively.

\begin{tabular}{|c|c|c|}
\hline & $(1)$ & $(2)$ \\
\hline \multirow[t]{2}{*}{ Control-ownership wedge } & -2.487 & -2.527 \\
\hline & $(0.843)^{* * *}$ & $(0.809)^{* * *}$ \\
\hline \multirow[t]{2}{*}{ Z-score } & -5.817 & \\
\hline & $(2.367)^{* *}$ & \\
\hline \multirow[t]{2}{*}{ Z-score $\times$ Wedge } & 0.264 & \\
\hline & $(0.105)^{* *}$ & \\
\hline \multirow[t]{2}{*}{ Distance to default } & & -0.038 \\
\hline & & $(0.015)^{* *}$ \\
\hline \multirow[t]{2}{*}{ Distance to default $\times$ Wedge } & & 0.211 \\
\hline & & $(0.090)^{* *}$ \\
\hline \multirow[t]{2}{*}{ Cash-flow rights } & 0.014 & 0.012 \\
\hline & $(0.017)$ & $(0.014)$ \\
\hline \multirow[t]{2}{*}{ Leverage } & -0.088 & -0.047 \\
\hline & $(0.035)^{* *}$ & $(0.021)^{* *}$ \\
\hline \multirow[t]{2}{*}{ Tangibility } & -0.051 & -0.069 \\
\hline & $(0.025)^{* *}$ & $(0.038)^{*}$ \\
\hline \multirow[t]{2}{*}{ Log assets } & -0.042 & -0.031 \\
\hline & $(0.017)^{* *}$ & $(0.014)^{* *}$ \\
\hline \multirow[t]{2}{*}{ Profitability } & -0.003 & -0.004 \\
\hline & $(0.002)^{*}$ & $(0.002)^{* *}$ \\
\hline \multirow[t]{2}{*}{$Q$} & -0.049 & -0.033 \\
\hline & $(0.023)^{* *}$ & $(0.016)^{* *}$ \\
\hline Industry effects & Yes & Yes \\
\hline Country $\times$ Time effects & Yes & Yes \\
\hline Number of observations & 43,273 & 43,502 \\
\hline Number of firms & 9,783 & 9,831 \\
\hline Adjusted $R^{2}$ & 0.130 & 0.129 \\
\hline
\end{tabular}




\section{Table 4}

Information opacity and the effect of the control-ownership wedge on debt choice

This table presents regression results on the effect of firm information opacity on the relation between the control-ownership wedge and debt choice. The dependent variable is the ratio of bank debt to total debt. The control-ownership wedge is defined as the difference between the control rights and cash-flow rights of the largest ultimate owner of the firm. Stock index inclusion is a dummy variable that equals one if the firm is included in a major national stock index and zero otherwise. Number of analysts is the total number of stock analysts following the firm. Volatility of accruals is an empirical measure of accrual quality (Dechow and Dichev, 2002; McNichols, 2002). Detailed definitions of all the variables are reported in Table 1A. Robust standard errors clustered by firm are reported in parentheses. Significance at the $10 \%, 5 \%$, and $1 \%$ level is indicated by $* * *$, and $* * *$, respectively.

\begin{tabular}{|c|c|c|c|c|}
\hline & $(1)$ & $(2)$ & (3) & $(4)$ \\
\hline Control-ownership wedge & $\begin{array}{l}-2.724 \\
(0.538)^{* * *}\end{array}$ & $\begin{array}{l}-2.185 \\
(0.762)^{* * *}\end{array}$ & $\begin{array}{l}-2.194 \\
(0.905)^{* *}\end{array}$ & $\begin{array}{l}-1.875 \\
(0.636)^{* * *}\end{array}$ \\
\hline Log assets & $\begin{array}{l}-0.044 \\
(0.017)^{* *}\end{array}$ & $\begin{array}{l}-0.038 \\
(0.016)^{* *}\end{array}$ & $\begin{array}{l}-0.041 \\
(0.018)^{* *}\end{array}$ & $\begin{array}{l}-0.037 \\
(0.016)^{* *}\end{array}$ \\
\hline Log assets $\times$ Wedge & $\begin{array}{l}0.116 \\
(0.053)^{* *}\end{array}$ & & & \\
\hline Stock index inclusion & & $\begin{array}{l}-0.179 \\
(0.078)^{* *}\end{array}$ & & \\
\hline Stock index inclusion $\times$ Wedge & & $\begin{array}{l}0.887 \\
(0.270)^{* * *}\end{array}$ & & \\
\hline Number of analysts & & & $\begin{array}{l}-0.015 \\
(0.006)^{* *}\end{array}$ & \\
\hline Number of analysts $\times$ Wedge & & & $\begin{array}{l}0.062 \\
(0.028)^{* *}\end{array}$ & \\
\hline Volatility of accruals & & & & $\begin{array}{l}0.479 \\
(0.201)^{* *}\end{array}$ \\
\hline Volatility of accruals $\times$ Wedge & & & & $\begin{array}{l}-1.581 \\
(0.710)^{* *}\end{array}$ \\
\hline Cash-flow rights & $\begin{array}{l}0.062 \\
(0.072)\end{array}$ & $\begin{array}{l}0.060 \\
(0.075)\end{array}$ & $\begin{array}{l}0.025 \\
(0.024)\end{array}$ & $\begin{array}{l}0.033 \\
(0.039)\end{array}$ \\
\hline Leverage & $\begin{array}{l}-0.049 \\
(0.021)^{* *}\end{array}$ & $\begin{array}{l}-0.033 \\
(0.014)^{* *}\end{array}$ & $\begin{array}{l}-0.032 \\
(0.014)^{* *}\end{array}$ & $\begin{array}{l}-0.053 \\
(0.022)^{* *}\end{array}$ \\
\hline Tangibility & $\begin{array}{l}-0.060 \\
(0.027)^{* *}\end{array}$ & $\begin{array}{l}-0.066 \\
(0.031)^{* *}\end{array}$ & $\begin{array}{l}-0.031 \\
(0.023)\end{array}$ & $\begin{array}{l}-0.021 \\
(0.016)\end{array}$ \\
\hline Profitability & $\begin{array}{l}-0.002 \\
(0.001)^{* *}\end{array}$ & $\begin{array}{l}-0.001 \\
(0.001)\end{array}$ & $\begin{array}{l}-0.001 \\
(0.001)^{*}\end{array}$ & $\begin{array}{l}-0.001 \\
(0.001)\end{array}$ \\
\hline$Q$ & $\begin{array}{l}-0.010 \\
(0.005)^{* *}\end{array}$ & $\begin{array}{l}-0.018 \\
(0.008)^{* *}\end{array}$ & $\begin{array}{l}-0.020 \\
(0.009)^{* *}\end{array}$ & $\begin{array}{l}-0.024 \\
(0.011)^{* *}\end{array}$ \\
\hline Distance to default & $\begin{array}{l}-0.020 \\
(0.009)^{* *}\end{array}$ & $\begin{array}{l}-0.014 \\
(0.006)^{* *}\end{array}$ & $\begin{array}{l}-0.018 \\
(0.008)^{* *}\end{array}$ & $\begin{array}{l}-0.012 \\
(0.005)^{* *}\end{array}$ \\
\hline Industry effects & Yes & Yes & Yes & Yes \\
\hline Country $\times$ Time effects & Yes & Yes & Yes & Yes \\
\hline Number of observations & 43,502 & 43,502 & 43,502 & 41,169 \\
\hline Number of firms & 9,831 & 9,831 & 9,831 & 8,760 \\
\hline Adjusted $R^{2}$ & 0.129 & 0.131 & 0.138 & 0.127 \\
\hline
\end{tabular}




\section{Table 5}

Family ownership and the effect of the control-ownership wedge on debt choice

This table presents regression results on the effect of family ownership on the relation between the control-ownership wedge and debt choice. The dependent variable is the ratio of bank debt to total debt. The control-ownership wedge is defined as the difference between the control rights and cash-flow rights of the largest ultimate owner of the firm. Family ownership is a dummy variable that equals one if the largest ultimate owner of the firm is a family or an individual and zero otherwise. Definitions of all the other variables are reported in Table 1A. Robust standard errors clustered by firm are reported in parentheses. Significance at the $10 \%, 5 \%$, and $1 \%$ level is indicated by $* * *$, and $* * *$, respectively.

\begin{tabular}{ll}
\hline Control-ownership wedge & -1.604 \\
& $(0.560)^{* * *}$ \\
Family ownership & 0.012 \\
& $(0.010)$ \\
Family ownership $\times$ Wedge & -1.382 \\
& $(0.393)^{* * *}$ \\
Cash-flow rights & 0.051 \\
& $(0.062)$ \\
Leverage & -0.069 \\
& $(0.028)^{* *}$ \\
Tangibility & -0.044 \\
& $(0.033)$ \\
Log assets & -0.039 \\
& $(0.018)^{* *}$ \\
Profitability & -0.002 \\
& $(0.001)$ \\
$Q$ & -0.023 \\
Distance to default & $(0.010)^{* *}$ \\
Industry effects & -0.016 \\
Country $\times$ Time effects & $(0.007)^{* *}$ \\
Number of observations & \\
Number of firms & Yes \\
Adjusted $R^{2}$ & Yes \\
& 43,502 \\
& 9,831 \\
& 0.130 \\
\hline
\end{tabular}




\section{Table 6}

The presence of multiple large shareholders and the effect of the control-ownership wedge on debt choice

This table presents regression results on the effect of the presence of multiple large shareholders on the relation between the control-ownership wedge and debt choice. The dependent variable is the ratio of bank debt to total debt. The control-ownership wedge is defined as the difference between the control rights and cash-flow rights of the largest ultimate owner of the firm. Multiple large owners is a dummy variable that equals one if the firm has at least one other owner besides the ultimate largest owner that has $10 \%$ or more of the voting rights. Definitions of all the other variables are reported in Table 1A. Robust standard errors clustered by firm are reported in parentheses. Significance at the $10 \%, 5 \%$, and $1 \%$ level is indicated by $* * *$, and $* * *$, respectively.

\begin{tabular}{ll}
\hline Control-ownership wedge & -2.281 \\
& $(0.773)^{* * *}$ \\
Multiple large owners & 0.007 \\
& $(0.008)$ \\
Multiple large owners $\times$ Wedge & 0.748 \\
& $(0.334)^{* *}$ \\
Cash-flow rights & 0.028 \\
& $(0.041)$ \\
Leverage & -0.075 \\
& $(0.033)^{* *}$ \\
Tangibility & -0.055 \\
& $(0.026)^{* *}$ \\
Log assets & -0.027 \\
& $(0.013)^{* *}$ \\
Profitability & -0.003 \\
& $(0.001)^{* *}$ \\
$Q$ & -0.029 \\
Distance to default & $(0.015)^{*}$ \\
& -0.022 \\
Industry effects & $(0.010)^{* *}$ \\
Country $\times$ Time effects & \\
Number of observations & Yes \\
Number of firms & Yes \\
Adjusted $R^{2}$ & 43,502 \\
& 9,831 \\
& 0.129 \\
\hline & \\
& \\
&
\end{tabular}




\section{Table 7}

Shareholder rights and the effect of the control-ownership wedge on debt choice

This table presents regression results on the effect of shareholder rights on the relation between the control-ownership wedge and debt choice. The dependent variable is the ratio of bank debt to total debt. The control-ownership wedge is defined as the difference between the control rights and cash-flow rights of the largest ultimate owner of the firm. Anti-self-dealing is an index compiled by Djankov et al. (2008) that measures legal protection of minority shareholders against self-dealing. Anti-director is an index compiled by La Porta et al. (1998) and Djankov et al. (2008) aggregating shareholder rights concerning voting and minority protection. Definitions of all the other variables are reported in Table 1A. Robust standard errors clustered by firm are reported in parentheses. Significance at the $10 \%, 5 \%$, and $1 \%$ level is indicated by $*, * *$, and $* * *$, respectively.

\begin{tabular}{|c|c|c|}
\hline & (1) & $(2)$ \\
\hline Control-ownership wedge & $\begin{array}{l}-2.696 \\
(0.907) * * *\end{array}$ & $\begin{array}{l}-2.469 \\
(0.823)^{* * *}\end{array}$ \\
\hline Anti-self-dealing & $\begin{array}{l}-0.098 \\
(0.042)^{* *}\end{array}$ & \\
\hline Anti-self-dealing $\times$ Wedge & $\begin{array}{l}0.481 \\
(0.176)^{* * *}\end{array}$ & \\
\hline Anti-director & & $\begin{array}{l}-0.023 \\
(0.015)\end{array}$ \\
\hline Anti-director $\times$ Wedge & & $\begin{array}{l}0.064 \\
(0.025)^{* *}\end{array}$ \\
\hline Cash-flow rights & $\begin{array}{l}0.027 \\
(0.039)\end{array}$ & $\begin{array}{l}0.022 \\
(0.025)\end{array}$ \\
\hline Leverage & $\begin{array}{l}-0.030 \\
(0.013)^{* *}\end{array}$ & $\begin{array}{l}-0.031 \\
(0.014)^{* *}\end{array}$ \\
\hline Tangibility & $\begin{array}{l}-0.071 \\
(0.039) *\end{array}$ & $\begin{array}{l}-0.077 \\
(0.037)^{* *}\end{array}$ \\
\hline Log assets & $\begin{array}{l}-0.012 \\
(0.006)^{* *}\end{array}$ & $\begin{array}{l}-0.044 \\
(0.021)^{* *}\end{array}$ \\
\hline Profitability & $\begin{array}{l}-0.002 \\
(0.001)^{* *}\end{array}$ & $\begin{array}{l}-0.002 \\
(0.001)^{*}\end{array}$ \\
\hline$Q$ & $\begin{array}{l}-0.034 \\
(0.016)^{* *}\end{array}$ & $\begin{array}{l}-0.024 \\
(0.013)^{*}\end{array}$ \\
\hline Distance to default & $\begin{array}{l}-0.019 \\
(0.008)^{* *}\end{array}$ & $\begin{array}{l}-0.012 \\
(0.005)^{* *}\end{array}$ \\
\hline Industry effects & Yes & Yes \\
\hline Time effects & Yes & Yes \\
\hline Number of observations & 43,502 & 43,502 \\
\hline Number of firms & 9,831 & 9,831 \\
\hline Adjusted $R^{2}$ & 0.071 & 0.071 \\
\hline
\end{tabular}




\section{Table 8}

Borrowing firm propping potential

This table presents regression results on the effect of propping potential on the relation between the controlownership wedge and debt choice. The dependent variable is the ratio of bank debt to total debt. The controlownership wedge is defined as the difference between the control rights and cash-flow rights of the largest ultimate owner of the firm. Propping potential is defined in Column 1 as the total value of the assets of all firms that are positioned below the borrowing firm in the ownership chain, divided by the borrowing firm's total assets, and in Column 2 as a weighted sum of the asset values of all firms lower down in the ownership chain divided by the borrowing firm's total assets, with the weight for each firm beneath the borrowing firm defined as the ultimate controlling shareholder's control rights in that firm. The sample used in Columns 1 and 2 include all firms belonging to pyramids. We then split this pyramid sample into two subsamples: one consisting of firms whose propping potential is positive (Column 3) and the other consisting of firms whose propping potential is zero (Column 4). Detailed definitions of all the variables are reported in Table 1A. Robust standard errors clustered by firm are reported in parentheses. Significance at the $10 \%, 5 \%$, and $1 \%$ level is indicated by $*, * *$, and $* * *$, respectively.

\begin{tabular}{|c|c|c|c|c|}
\hline & (1) & (2) & (3) & (4) \\
\hline & $\begin{array}{l}\text { Pyramid } \\
\text { sample }\end{array}$ & $\begin{array}{l}\text { Pyramid } \\
\text { sample }\end{array}$ & $\begin{array}{l}\text { Positive propping } \\
\text { potential }\end{array}$ & $\begin{array}{l}\text { Zero propping } \\
\text { potential }\end{array}$ \\
\hline \multirow[t]{2}{*}{ Control-ownership wedge } & -2.801 & -2.765 & -2.164 & -3.671 \\
\hline & $(0.491)^{* * *}$ & $(0.513)^{* * *}$ & $(0.318)^{* * *}$ & $(0.461)^{* * *}$ \\
\hline \multirow[t]{2}{*}{ Propping potential } & -0.128 & -0.644 & & \\
\hline & $(0.051)^{* *}$ & $(0.243)^{* * *}$ & & \\
\hline \multirow[t]{2}{*}{ Cash-flow rights } & 0.022 & 0.020 & 0.047 & 0.018 \\
\hline & $(0.031)$ & $(0.024)$ & $(0.050)$ & $(0.020)$ \\
\hline \multirow[t]{2}{*}{ Leverage } & -0.037 & -0.032 & -0.040 & -0.029 \\
\hline & $(0.016)^{* *}$ & $(0.013)^{* *}$ & $(0.017)^{* *}$ & $(0.011)^{* *}$ \\
\hline \multirow[t]{2}{*}{ Tangibility } & -0.061 & -0.058 & -0.067 & -0.052 \\
\hline & $(0.028)^{* *}$ & $(0.039)$ & $(0.048)$ & $(0.035)$ \\
\hline \multirow[t]{2}{*}{ Log assets } & -0.038 & -0.037 & -0.038 & -0.032 \\
\hline & $(0.016)^{* *}$ & $(0.016)^{* *}$ & $(0.016)^{* *}$ & $(0.013)^{* *}$ \\
\hline \multirow[t]{2}{*}{ Profitability } & -0.003 & -0.002 & -0.002 & -0.003 \\
\hline & $(0.002)$ & $(0.001)$ & $(0.001)^{* *}$ & $(0.001)^{* *}$ \\
\hline \multirow[t]{2}{*}{$Q$} & -0.034 & -0.028 & -0.029 & -0.035 \\
\hline & $(0.015)^{* *}$ & $(0.016)^{*}$ & $(0.013)^{* *}$ & $(0.019)^{*}$ \\
\hline \multirow[t]{2}{*}{ Distance to default } & -0.018 & -0.014 & -0.022 & -0.013 \\
\hline & $(0.007)^{* *}$ & $(0.006)^{* *}$ & $(0.010)^{* *}$ & $(0.005)^{* *}$ \\
\hline Industry effects & Yes & Yes & Yes & Yes \\
\hline Country $\times$ Time effects & Yes & Yes & Yes & Yes \\
\hline Number of observations & 27,592 & 27,592 & 20,700 & 6,892 \\
\hline Number of firms & 6,514 & 6,514 & 4,424 & 2,244 \\
\hline Adjusted $R^{2}$ & 0.108 & 0.114 & 0.105 & 0.098 \\
\hline
\end{tabular}




\section{Table 9}

Level of bank debt

This table presents regression results on the effect of the level of bank debt on the relation between the control-ownership wedge and debt choice. The dependent variable is the ratio of bank debt to total debt. We split our sample into two groups based on the sample median bank debt-to-total debt ratio. The control-ownership wedge is defined as the difference between the control rights and cash-flow rights of the largest ultimate owner of the firm. Definitions of all the other variables are reported in Table 1A. Robust standard errors clustered by firm are reported in parentheses. Significance at the $10 \%, 5 \%$, and $1 \%$ level is indicated by $* * *$, and $* * *$, respectively.

\begin{tabular}{lll}
\hline & $(1)$ & $(2)$ \\
\cline { 2 - 3 } Control-ownership wedge & -1.601 & Low bank debt ratio \\
Cash-flow rights & $(0.255)^{* * *}$ & -2.612 \\
& 0.039 & $(0.310)^{* * *}$ \\
Leverage & $(0.041)$ & 0.043 \\
& -0.048 & $(0.051)$ \\
Tangibility & $(0.019)^{* *}$ & -0.071 \\
& -0.043 & $(0.029)^{* *}$ \\
Log assets & $(0.028)$ & -0.067 \\
Profitability & -0.036 & $(0.043)$ \\
& $(0.015)^{* *}$ & -0.031 \\
Q & -0.002 & $(0.014)^{* *}$ \\
Distance to default & $(0.001)^{* *}$ & -0.003 \\
Industry effects & -0.029 & $(0.001)^{* *}$ \\
Country $\times$ Time effects & $(0.014)^{* *}$ & -0.048 \\
Number of observations & -0.022 & $(0.023)^{* *}$ \\
Number of firms & $(0.009)^{* *}$ & -0.026 \\
Adjusted $R^{2}$ & & $(0.011)^{* *}$ \\
\hline
\end{tabular}




\section{Table 10}

Change regressions

This table presents regression results on the effect of a change in a firm's control-ownership wedge on the change in the firm's debt structure. The dependent variable is the change in the ratio of bank debt to total. The control-ownership wedge is defined as the difference between the control rights and cashflow rights of the largest ultimate owner of the firm. Definitions of all the other variables are reported in Table 1A. Robust standard errors clustered by firm are reported in parentheses. Significance at the $10 \%$, $5 \%$, and $1 \%$ level is indicated by $* * *$, and $* * *$, respectively.

\begin{tabular}{lll}
\hline & $(1)$ & $(2)$ \\
\hline$\Delta$ Control-ownership wedge & -1.562 & -1.418 \\
$\Delta$ Cash-flow rights & $(0.416)^{* * *}$ & $(0.480)^{* * *}$ \\
& 0.021 & 0.017 \\
$\Delta$ Leverage & $(0.039)$ & $(0.034)$ \\
& & -0.035 \\
$\Delta$ Tangibility & $(0.016)^{* *}$ \\
& & -0.034 \\
$\Delta$ Log assets & $(0.024)$ \\
& & -0.022 \\
$\Delta$ Profitability & & $(0.010)^{* *}$ \\
& & -0.003 \\
$\Delta Q$ & & $(0.001)^{* *}$ \\
$\Delta$ Distance to default & -0.016 \\
& & $(0.007)^{* *}$ \\
& & -0.017 \\
Number of observations & 12,817 & $(0.008)^{* *}$ \\
Number of firms & 3,841 & 12,817 \\
Adjusted $R^{2}$ & 0.056 & 3,841 \\
\hline
\end{tabular}




\section{Table 11}

Instrumental variable regressions

This table presents the instrumental variable regression results on the effect of the control-ownership wedge on debt choice. The dependent variable is the ratio of bank debt to total debt. The controlownership wedge is defined as the difference between the control rights and cash-flow rights of the largest ultimate owner of the firm. The instruments for the control-ownership wedge and cash-flow rights are the initial country-specific industry average wedge and average cash-flow rights, respectively. Definitions of all the other variables are reported in Table 1A. Robust standard errors clustered by firm are reported in parentheses. Significance at the $10 \%, 5 \%$, and $1 \%$ level is indicated by $*, * *$, and ***, respectively.

\begin{tabular}{lll}
\hline & $(1)$ & $(2)$ \\
\hline Control-ownership wedge & -3.671 & -3.368 \\
& $(0.486)^{* * *}$ & $(0.472)^{* * *}$ \\
Cash-flow rights & 0.052 & 0.049 \\
& $(0.067)$ & $(0.078)$ \\
Leverage & & -0.041 \\
& & $(0.017)^{* *}$ \\
Tangibility & & -0.073 \\
& & $(0.047)$ \\
Log assets & & -0.025 \\
& & $(0.011)^{* *}$ \\
Profitability & & -0.003 \\
& & $(0.001)^{* *}$ \\
$Q$ & & -0.051 \\
& & $(0.022)^{* *}$ \\
Distance to default & & -0.024 \\
& & $(0.009)^{* * *}$ \\
Industry effects & & \\
Country $\times$ Time effects & Yes & Yes \\
Number of observations & Yes & Yes \\
Number of firms & 43,502 & 43,502 \\
Adjusted $R^{2}$ & 9,831 & 9,831 \\
\hline & 0.095 & 0.129 \\
\hline
\end{tabular}




\section{Table 12}

The effect of control-ownership wedge on debt maturity and security

This table presents the OLS regression results on the effects of control-ownership wedge on debt maturity and on debt security. The dependent variables are the proportion of total debt maturing in more than 3 years in Column 1 and the proportion of total debt maturing in more than 5 years in Column 2. The dependent variable in Column 3 is the proportion of total debt secured by collateral. The controlownership wedge is defined as the difference between the control rights and cash-flow rights of the largest ultimate owner of the firm. Definitions of all the other variables are reported in Table 1A. Robust standard errors clustered by firm are reported in parentheses. Significance at the $10 \%, 5 \%$, and $1 \%$ level is indicated by $* * *$, and $* * *$, respectively.

\begin{tabular}{|c|c|c|c|}
\hline & (1) & (2) & (3) \\
\hline & $\begin{array}{l}\text { Debt maturity } \\
\text { (due after } 3 \text { years) }\end{array}$ & $\begin{array}{l}\text { Debt maturity } \\
\text { (due after } 5 \text { years) }\end{array}$ & Debt security \\
\hline Control-ownership wedge & $\begin{array}{l}0.538 \\
(0.226)^{* *}\end{array}$ & $\begin{array}{l}0.320 \\
(0.133)^{* *}\end{array}$ & $\begin{array}{l}-0.520 \\
(0.221)^{* *}\end{array}$ \\
\hline Cash-flow rights & $\begin{array}{l}-0.056 \\
(0.050)\end{array}$ & $\begin{array}{l}-0.083 \\
(0.084)\end{array}$ & $\begin{array}{l}0.042 \\
(0.045)\end{array}$ \\
\hline Leverage & $\begin{array}{l}0.065 \\
(0.031)^{* *}\end{array}$ & $\begin{array}{l}0.032 \\
(0.015)^{* *}\end{array}$ & $\begin{array}{l}0.205 \\
(0.093)^{* *}\end{array}$ \\
\hline Tangibility & $\begin{array}{l}0.058 \\
(0.031)^{*}\end{array}$ & $\begin{array}{l}0.066 \\
(0.030)^{* *}\end{array}$ & $\begin{array}{l}-0.164 \\
(0.086)^{*}\end{array}$ \\
\hline Log assets & $\begin{array}{l}0.026 \\
(0.011)^{* *}\end{array}$ & $\begin{array}{l}0.025 \\
(0.012)^{* *}\end{array}$ & $\begin{array}{l}0.031 \\
(0.014)^{* *}\end{array}$ \\
\hline Profitability & $\begin{array}{l}0.022 \\
(0.023)\end{array}$ & $\begin{array}{l}0.015 \\
(0.017)\end{array}$ & $\begin{array}{l}-0.048 \\
(0.028)^{*}\end{array}$ \\
\hline$Q$ & $\begin{array}{l}-0.013 \\
(0.007)^{*}\end{array}$ & $\begin{array}{l}-0.012 \\
(0.005)^{* *}\end{array}$ & $\begin{array}{l}-0.043 \\
(0.020)^{* *}\end{array}$ \\
\hline Distance to default & $\begin{array}{l}0.003 \\
(0.002)^{*}\end{array}$ & $\begin{array}{l}0.005 \\
(0.002)^{* *}\end{array}$ & $\begin{array}{l}-0.004 \\
(0.002)^{* *}\end{array}$ \\
\hline Industry effects & Yes & Yes & Yes \\
\hline Country $\times$ Time effects & Yes & Yes & Yes \\
\hline Number of observations & 42,961 & 42,961 & 42,961 \\
\hline Number of firms & 9,808 & 9,808 & 9,808 \\
\hline Adjusted $R^{2}$ & 0.089 & 0.074 & 0.196 \\
\hline
\end{tabular}

